\title{
PENGARUH PENGENDALIAN INTERNAL DAN GOOD CORPORATE GOVERNANCE TERHADAP PN CEGAHAN FRAUD
}

\author{
Rusman Soleman \\ Fakultas Ekonomi, Universitas Khairun Ternate \\ e-mail: rusmansoleman@ rocketmail.com
}

\begin{abstract}
The study aimed to exam the effect of internal control and good corporate governance on fraud prevention. There are 72 Local Government SKPD North Maluku Province used as the unit of research and serve as a sample of respondents is 144 people with using a non purposive random sampling. Data obtained from interviews using questionnaires. Corfirmatory Factor Analysis showed indicators $X 1, X 2$, and $Y$ has good validity and reliability. The results of this study demonstrated that: 1) internal control positive effect on fraud prevention, 2) internal control positive effect on good corporate governance; and 3) good corporate governance positive effect on fraud prevention. Therefore, this study proposes to the Government throughout the province of North Maluku regency / city to design a comprehensive system of internal control in order to preventive fraud, and leaders must set priorities, coordinate strategy and communication it to the rest of management and staff.
\end{abstract}

Keywords: Internal Control, Good Corporate Governance, and Fraud Prevention.

\begin{abstract}
Abstrak
Tujuan penelitian ini adalah mengetahui pengaruh pengendalian internal dan good corporate governance terhadap pencegahan fraud. Terdapat 72 SKPD Pemerintah Daerah Provinsi Maluku Utara yang dijadikan unit penelitian dan sampel yang dijadikan sebagai responden adalah sebanyak 144 orang dengan menggunakan purposive non random sampling. Data diperoleh dari hasil wawancara dengan menggunakan kuesioner. Analisis faktor konfirmatori menunjukan indikator $\mathrm{X} 1, \mathrm{X} 2$, dan $\mathrm{Y}$ memiliki validitas dan reliabilitas yang baik. Hasil penelitian ini menunjukkan: 1) Pengendalian internal berpengaruh positif terhadap pencegahan fraud; 2) Pengendalian internal berpengaruh positif terhadap Good Corporate Governance, dan 3) Good Corporate Governance berpengaruh positif terhadap pencegahan fraud. Karena itu, penelitian ini mengusulkan kepada Pemerintah Provinsi Maluku Utara di seluruh Kabupaten/kota mendesain sistem pengendalian internal secara komprehensip agar dapat mencegah terjadinya fraud, dan pimpinan harus menetapkan prioritas, mengkoordinasikan strategi dan mengkomunikasikannya ke seluruh manajemen dan staf.
\end{abstract}

Kata Kunci: Pengendalian Internal, Good Corporate Governance, dan Pencegahan Fraud.

\section{PENDAHULUAN}

Undang-undang di bidang Keuangan Negara yaitu Undang-Undang No 17 Tahun 2003 dan UU No 1 Tahun 2004 tentang Perbendaharaan Negara dan UU No.15 Tahun 2004 Tentang Pemeriksaan Pengelolaan Keuangan Negara menitikberatkan adanya asas pengelolaan Keuangan Negara yang mengarah pada best practice dalam rangka pencapaian good governance. Ukuran good governance diantara- nya adalah menggunakan asas akuntabilitas berorientasi hasil atau yang lebih dikenal dengan istilah akuntabilitas kinerja dan transparansi dalam pengelolaan keuangan negara.

Menurut Mardiasmo (2002) terdapat tiga aspek penting yang mendukung keberhasilan otonomi daerah, yaitu pengawasan, pengendalian dan pemeriksaaan. Pengendalian adalah mekanisme yang dilakukan oleh eksekutif (pemerintah daerah) untuk menjamin di- 
laksanakannya sistem dan kebijakan manajemen dengan baik, sehingga tujuan organisasi dapat tercapai. Pengendalian internal merupakan salah satu bentuk pengendalian dimana dapat diperoleh dari suatu struktur yang terkoordinasi yang berguna bagi pimpinan untuk menyusun laporan keuanganya lebih hati-hati, mencegah kecurangan dalam organisasi serta mengamankan harta organisasi.

Tuanakotta (2013) menyatakan bahwa pengendalian internal dirancang, diimplementasikan dan dipelihara TCWG, manajemen dan karyawan lain untuk menangani resiko bisnis dan kecurangan yang diketahui (identified business and fraud risk) mengancam pencapaian tujuan entitas seperti pelaporan keuangan yang andal. Untuk itu pengendalian dimaksudkan untuk memberikan jawaban (response) untuk menangkal (mitigate) suatu ancaman (kemungkinan terjadinya resiko), sehingga manajemen menerapkan pengendalian agar supaya seluruh ancaman tekait dengan pengelolaan harta organisasi dapat dideteksi secara dini.

Menurut Pope dikutip oleh Kayo (2013) secara sederhana penyelewengan dapat dikatakan sebagai penyalagunaan kekuasaan kepercayaan untuk kepentingan. Selain itu, menurut Khanna (2009) kurangnya pelatihan, banyaknya beban yang dihadapi oleh pegawai serta persaingan dan tingkat kepatuhan yang rendah menjadi pemicu terjadinya kecurangan. Kondisi ini mestinya menyadarkan seluruh elemen untuk bertindak secara bersama-sama dengan cara memperbaiki tata kelola organisasi sehingga meminimalisir potensi terjadinya kecurangan di lingkungan organisasi. Tata kelola yang baik dan dibarengi dengan komitmen yang tinggi dikalangan pegawai akan berimplikasi pada kinerja keuangan organisasi yang efisien, akan tetapi rendahnya tata kelola serta minimnya komitmen organisasi maka akan berdampak buruk pada kinerja keuangan organisasi.

Menurut Arens, Elder \& Beasley (2008) bahwa fraud menggambarkan setiap upaya penipuan yang disengaja, yang dimaksudkan untuk mengambil harta atau hak orang atau pihak lain. Upaya kecurangan ini di dorong oleh berbagai kekuatan internal mupun eksternal yang dilakukan secara individu maupun secara kolektif. Sejalan dengan ini, Wells (2007) menyatakan bahwa kecurangan akuntansi (fraud) mengacu kepada kesalahan akuntansi yang dilakukan secara sengaja untuk tujuan menyesaatkan pembaca/pengguna laporan keuangan. Tujuan ini dilakukan dengan motivasi negatif guna mengambil keuntungan individu atau pihak-pihak tertentu. Menurut Association of certified fraud examiners (ACFE) kecurangan akuntansi digolongkan menjadi tiga jenis yaitu kecurangan dalam laporan keuangan, penyalagunaan aktiva dan korupsi.

Siaran Pers BPK R.I (2013) tentang hasil evaluasi atas sistem pengendaian internal yang dilakukan oleh BPK R.I mengungkapkan bahwa kasus-kasus kelemahan pengendalian internal dikelompokkan sebagai: a) kelemahan sistem pengendalian akuntansi dan pelaporan, b) kelemahan sistem pengendalian pelaksanaan anggaran pendapatan dan belanja, dan c) kelemahan pada sturktur pengendalian internal. Selain itu, siaran Pers BPK RI (2013) tentang hasil pemeriksaaan Kinerja pada pemerintah daerah seluruh Indonesia semester I tahun 2013 ditemukan 1 kasus ketidakhematan/ketidakekonomisan senilai Rp. 5,28 Milyar, 3 kasus ketidakefisienan senilai Rp. 22,95 Milyar dan 93 kasus ketidakefektifan senilai Rp. 19,45 Milyar. Hasil pemeriksaan kinerja juga mengungkapkan adanya 65 kasus kelemahan pengendalian internal yang mempengaruhi kehematan/ekonomi, efisiensi dan efektifitas serta 5 kasus ketidakpatuhan terhadap ketentuan perudang-undangan senilai $\mathrm{Rp} .1,36$ milyar. Selain itu, hasil pemeriksaan BPK RI sampai semester 1 tahun 2012 menunjukkan bahwa LKPD dari entitas pelaporan di wilayah Propinsi Maluku Utara menunjukan bahwa masih terdapat kelemahan dalam sistem pengendalian internal dan ketidak patuhan terhadap ketentuan perudang-undangan yang mengakibatkan kerugian daerah dilihat berdasarkan kelemahan SPI dengan jumlah kasus sebeanyak 45, dan ketidakpatuhan dengan jumlah kasus sebanyak 58 yang mencerminkan bahwa masih terdapat berbagai kelemahan 
dalam pengendalian internal sehingga memunculkan potensi kecurangan yang terjadi pada entitas pelaporan di wilayah Maluku Utara. Temuan BPK R.I ini konsisten dengan penelitian yang dilakukan oleh Liu dan Lin (2012), bahwa temuan audit berhubungan positif dengan tingkat korupsi yang terjadi pada sebuah daerah dan semakin baik fungsi internal audit akan berhubungan negatif dengan tingkat korupsi yang terjadi.

Konsep good corporate governance (GCG) muncul karena konflik kepentingan yang terjadi antara principal dan agent yang mendorong agen untuk menyajikan informasi yang tidak sebenarnya kepada principal, terutama jika informasi tersebut berkaitan dengan pengukuran kinerja agent. Penyajian informasi yang tidak wajar akan berdampak pada kebenaran informasi yang dibutuhkan oleh principal. Untuk itu penerapan GCG rupakan perwujudan tanggung jawab pemerintah dalam rangka peningkatan kinerja.

Berbagai kasus yang muncul dalam dunia bisnis yang dimulai dari kasus enron, word com, kasus bank lippo, bank BNI dan yang terakhir adalah kasus bank century adalah cerminan dari lemahnya pengendalian dan praktik tata kelola yang baik menyebabkan terjadinya fraud, fenomna ini tidak hanya terjadi di sektor swasta tetapi juga terjadi dalam pengelolaan keuangan di organisasi sektor publik yang tercermin dari opini BPK R.I terhadap laporan keuangan Pemerintah Daerah.

Berangkat dari berbagai fenomena diatas maka identifikasi masalah dalam penelitian ini adalah apakah terdapat pengaruh pengendalian internal dan good corporate governance terhadap pencegahan fraud di lingkungan Pemerintah Daerah Provinsi Maluku Utara.

\section{TINJAUAN PUSTAKA DAN PERU- MUSANHIPOTESIS \\ Pengendalian Internal (Internal Control)}

IAPI dikutip oleh Sukrisno (2012) mendefinisikan pengendalian internal sebagai suatu proses yang dijalankan oleh dewan komisaris, manajemen dan personel lain entitas-entitas yang didesain untuk memberikan keyakinan memadai tentang pencapaian tiga golongan tujuan yakni: keandalan pelaporan keuangan, efektivitas dan efisiensi operasi serta kepatuhan terhadap hukum dan peraturan yang berlaku.

Arens, dkk. (2008) menjelaskan bahwa sistem pengendalian internal terdiri atas kebijakan dan prosedur yang dirancang untuk memberikan manajemen kepastian yang layak bahwa perusahaan telah mencapai tujuan dan sasarannya. Kebijakan perusahaan inilah yang disebut dengan pengendalian dan secara kolektif disebut dengan pengendalian internal.

Sedangkan menurut Mayangsari \& Wandanarum (2013) pengendalian internal adalah penggunaan semua sumberdaya perusahaan untuk meningkatkan, mengarahkan, mengendalikan dan mengwasani berbagai aktivitas dengan tujuan untuk memastikan bahwa tujuan perusahaan tercapai. Untuk itu, demi tercapainya tujuan perusahaan tersebut, maka prosedur dan kebijakan harus dilakukan oleh perusahaan dengan cara setiap aktivitas yang dilakukan dalam perusahaan harus melalui sebuah sistem yang didesain untuk dapat mengarahkan, dan mengendalikan dan mengawasi rangkaian aktivitas sehingga tujuan perusahaan dapat dicapai secara efisien dan efektif.

Sedangkan Committee of Sponsoring Organization of the Treadway Commision (COSO) (1994 p 3) memberikan pengertian pengendalian internal sebagai berikut:

Internal control is broadly defined as a process, effected by an entity's board of directors, management, and other personnel, designed to provide reasonable assurance regarding the achievement of objectives.

Lebih lanjut dijelaskan bahwa komponen pengendalian internal dibagi menjadi lima (5) komponen inti yakni: 1) tujuan pelaporan, 2) lingkungan pengendalian, 3) penilaian resiko, 4) sistem informasi, dan 5) kegiatan pengendalian dan pemantauan.

Berbeda dengan Sunyoto (2014) bahwa menjelaskan bahwa pengendalian internal adalah sebuah sistem dimana sistem 
pengendalian internal terdiri atas kebijakan dan prosedur yang dirancang untuk memberikan kepastian yang layak bagi manajemen, bahwa organisasi telah mencapai tujuan dan sasaranya. Selain itu, menurut Sunyoto bahwa kompenen pengendalian internal dapat dikategorikan menjadi tiga (3) katogori dasar yaitu: 1) lingkungan pengendalian yang berkaitan dengan tindakan, kebijakan dan prosedur yang mencerminkan keseluruhan sikap manajemen puncak, direktur dan pemilik perusahaan terhadap pengendalian, 2) sistem akuntansi yang bertujuan untuk mengontrol seluruh taransaksi yang dicatat, diproses dan dilaporkan telah memenuhi ke enam tujuan audit umum atas transaksi tersebut, 3) prosedur pengendalian yaitu aktivitas pengendalian ini berhubungan dengan penilaian atas mutu pengendalian internal secara berkesinambungan oleh manajemen untuk menentukan bahwa pengendalian telah berjalan sebagaimana yang diharapkan dan dimodifikasi sesuai dengan kondisi yang ada dalam perusahaan. Ini menunjukan bahwa, pimpinan harus mampu merencanakan, dan mengevaluasi secara konsisten dan kontinyu, sehingga pengendalian berjalan sesuai dengan yang diinginkan. Apabila suatu pengendalian internal tidak dilakukan sesuai dengan sistem pengendalian yang diinginkan, maka proses pengendalian tidak berarti terhadap pencegahan fraud.

Terkait dengan hal di atas, menurut Tuanakotta (2013) pengendalian internal akan berjalan efektif manakalah komponen inti pengendalian internal diterapkan secara baik dan benar dalam organisasi guna memberikan kepastian terhadap pencapaian tujuan organisasi.

Berbagai penjelasan di atas menunjukan bahwa pengendalian internal harus dilakukan sesuai dengan prosedur dan kebijakan organisasi melalui sebuah sistem yang telah didesain sedemikian rupa serta perlu diawasi dengan baik dan benar. Hal ini perlu dilakukan, karena dapat mengurangi tingkat kecurangan diantaranya penyalahgunaan wewenang dan melakukan penyajian laporan keuangan yang salah. Ini juga berarti pengendalian internal secara efektif dapat memberi- kan kontribusi positif terhadap pencegahan fraud. Hal ini sejalan dengan hasil penelitian Tunji (2013) yang menemukan adanya sistem pengendalian internal yang efektif berpengaruh positif terhadap eleminasi penipuan yang dilakukan oleh direktur perbankan. Jadi, dengan adanya sistem pengendalian internal yang efektif memiliki dampak yang besar terhadap akurasi dan keandalan laporan keuangan bank. Selai itu, temuan penelitian ini juga menjelaskan bahwa ukuran keberhasilan perusahaan dapat dilihat pada kemampuan perusahaan untuk menerapkan prosedur dan kebijakan yang dirancang untuk memberikan kepastian yang layak bagi perusahaan dalam mencapai tujuan dan sasarannya.

Dengan demikian, untuk mencapai tujuan dan sasaran perusahaan atau organisasi apapun harus mampu merancang sistem pengendalian internal yang baik, sehingga dapat menekankan aspek pengendalian atas reabilitas pelaporan keuangan guna memenuhi tanggung jawab suatu laporan keuangan, serta efesiensi dan efektifitas operasional dalam pemakaian sumberdaya yang dimiliki oleh perusahaan untuk menghasilkan informasi keuangan dan non keuangan dalam rangka pengambilan keputusan, dan ketaatan pada hukum dan peraturan.

\section{Good Corparate Governance}

Istilah corporate governance (CG) diperkenalkan pertama kali oleh Cadbury Committee di tahun 1992. Sari (2012) mengemukakan, istilah tersebut muncul dalam laporan Cadbury Committee yang kemudian dikenal sebagai Cadbury Report. Cadbury Report sendiri mendefinisikan CG sebagai "the system by which organisations are directed and controlled". Lebih jauh, Cadbury Committee memandang CG sebagai seperangkat aturan yang merumuskan hubungan antara para pemegang saham, manajer, kreditor, pemerintah, karyawan, dan pihak-pihak yang berkepentingan lainnya baik internal maupun eksternal sehubungan dengan hak-hak dan tanggung jawab mereka.

Kusmayadi dikutip oleh Sari (2012), bahwa dalam prespektif sektor publik maka 
secara konseptual pengertian tata kelola pemerintahan (good corporate governance) yang baik mengandung dua pemahaman yaitu: 1) nilai yang mejunjung tinggi keinginan/kehendak rakyat, dan 2) nila nilai yang dapat meningkatkan kemampuan rakyat dalam pencapaian tujuan kemandirian, pembangunan berkelanjutan dan keadilan sosial.

Berbeda dengan Komite Nasional Kebijakan Governance (KNKG) prinsipprinsip tata kelola pemerintahan yang baik akan memberikan kontribusi yang strategis untuk: 1) meningkatkan kesejahteraan masyarakat; 2) mnciptakan iklim bisnis yang sehat; 3) meningkatkan kemampuan daya saing; dan 4) sangat efektif menghindari penyimpanganpenyimpangan dan mencegah terhadap korupsi dan suap.

Sedangkan United Nation Development Program (UNDP) merekomendasikan beberapa karakteristik tata kelola pemerintahan yang baik yaitu, legitimasi politik, kerjasama dengan institusi masyarakat sipil, kebebasan berasosiasi dan berpartisipasi, akuntabilitas birokrasi dan keuangan, manajemen sektor publik yang efisien, kebebasan informasi dan ekspresi, sistem yudisial yang adil dan dapat dipercaya.

Asian Development Bank (1999) sendiri menegaskan adanya konsensus umum bahwa tata kelola pemerintahan yang baik dilandasi oleh empat unsur yaitu: 1) accountability, 2) transparency, 3) predictability; dan 4) participation.

Sedangkan Tim Pengembangan Tata Kelola Pemerintahanan yang baik BPKP (2003), merumuskan lima prinsip yang melandasi tata kelola pemerintahan yang baik yaitu: 1) transparansi; 2) partisipasi 3) akuntabilitas; 4) kemandirian; dan 5) pertanggungjawaban. Pen jelasannya sebagai berikut: 1) Pertanggungjawaban (Responsibility) yaitu: kesesuaian di dalam pengelolahan perusahaan terhadap peraturan perundang-undangan yang berlaku dan prinsip-prinsip korporasi. Tanggung jawab perusahaan tidak hanya diberikan kepada pemegang saham juga kepada stakeholder tetapi juga kepada pihak-pihak yang berkepntingan lainnya; 2) Transparansi
(Transparency) yaitu: keterbukaan dalam melaksanakan proses pengambilan keputusan dan keterbukaan dalam mengemukakan informasi materiil dan relevan mengenai perusahan. Perusahaan harus menyediakan informasi yang material dan relevan dengan cara yang mudah diakses dan dipahami oleh pemangku kepentingan mengenai struktur dan operasi korporasi; 3) Akuntabilitas (Accountability) yaitu kejelasan fungsi, pelaksanaan, dan tanggung jawab organ sehingga pengelolaan perusahaan terlaksana secara efektif. Perusahaan harus dapat mempertanggung jawabkan kinerjanya secara transparan dan wajar; 4) Kesetaraan dan Kewajaran (Fairness) yaitu: keadilan dan kesetaraan di dalam memenuhi hak-hak stakeholder yang timbul berdasarkan perjanjian dan peraturan perundang-undangan yang berlaku. Dalam melaksanakan kegiatannya, perusahaan harus senantiasa memperhatikan kepentingan pemegang saham dan pemangku kepentingan lainnya berdasarkan asas kesetaraan dan kewajaran; dan 5) Independensi (Independency) yaitu suatu keadaan di mana perusahaan dikelola secara professional tanpa benturan kepentingan dan pengaruh/tekanan dari pihak manapun yang tidak sesuai dengan peraturan perundang-undangan yang berlaku dan prinsip-prinsip korporasi yang sehat. Untuk melancarkan pelaksanaan asas Good Corporate Governance, perusahaan harus dikelola secara independen sehingga masing-masing organ perusahaan tidak saling mendominasi dan tidak dapat diintervensi oleh pihak lain.

Dari berbagai penjelasan di atas dapat dipahami bahwa GCG merupakan suatu sistem yang ada dalam organisasi dan diterapkan dalam rangka mencapai kinerja organisasi semaksimal mungkin dengan cara-cara yang tidak merugikan stakeholder suatu organisasi. Maksudnya adalah dengan diterapkannya GCG, organisasi pemerintah diharapkan mampu mengatasi berbagai masalah akibat benturan kepentingan antara pihak-pihak terkait atau pemangku kepentingan lainnya. Selain faktor tata kelola yang diuraikan tersebut, faktor lain yang juga berperan penting yaitu kualitas, kemampuan, integritas dan 
kredibilitas berbagai pihak yang menggerakkan organisasi.

\section{Kecurangan (Fraud)}

Association of Cerified Fraud Examiners (ACFA) (2012) mengkategorikan kecurangan dalam tiga kelompok yaitu: 1) kecurangan dalam laporan keuangan, 2) penyalagunaan aset, dan 3) korupsi. Sementara itu menurut Ikatan Akuntan Indonesia (IAI) kecurangan akuntansi sebagai: 1) salah saji yang timbul dari kecurangan dalam pelaporan keuangan yaitu salah saji atau penghilangan secara sengaja jumlah atau pengungkapan dalam laporan keuangan untuk mengelabui pemakai laporan keuangan, 2) salah saji yang timbul dari perilaku tidak semestinya terhadap aktiva (seringkali disebut dengan penyalahgunaan atau penggelapan) yang berkaitan dengan pencurian aktiva entitas yang berakibat laporan keuangan tidak disajikan sesuai dengan prinsip akuntansi berlaku umum (PABU) di Indonesia.

Menurut Tunggal (2011) fraud adalah penipuan yang disengaja, umumnya diterangkan berbagai kebohongan, penjiplakan, pencurian dan kecurangan ini dapat dilakukan oleh pelanggan, kreditor, investor, pemasok, banker, penjamin asuransi atau pihak pemerintah. Ini berati bahwa, kecurangan tidak hanya dilakukan oleh orang didalam organisasi tetapi juga pihak luar (eksternal) memiliki peluang yang sama untuk melakukan kecurangan. Hal ini dapat dilakukan dengan berbagai cara oleh orang yang memiliki kecerdasan. Sejalan dengan ini, Albrecht, et al. (2009) menyatakan bahwa secara umum fraud dapat didefinisikan sebagai satu istilah umum dan mencakup semua cara yang dapat dirancang oleh kecerdasan manusia, yang melalui satu individu, untuk memperoleh keuntungan dari orang lain dengan penyajian yang salah. Tidak ada aturan yang pasti dan seragam untuk dijadikan dasar dalam mendefinisikan fraud karena mencakup kejutan penipuan, kelicikan dan cara-cara lain dimana pihak lain dicurangi. Sejalan dengan ini, Arens, dkk. (2008), menggambarkan bahwa kecurangan (fraud) adalah setiap upaya penipuan yang disengaja, yang dimaksudkan untuk mengambil harta atau hak orang atau pihak lain. Ini berarti bahwa kecurangan merupakan salah saji laporan keuangan yang disengaja. Ukuran salah saji yang dilakukan adalah penyalahgunaan aktiva dan penyajian laporan keuangan secara curang. Penyajian laporan keuangan yang curang dilakukan dengan cara mengabaikan jumlah dan pengungkapan yang disengaja dengan maksud untuk membuat pembaca laporan keuangan keliru dalam memahami isi laporan keuangan. Sedangkan penyalahgunaan aktiva berkaitan dengan perilaku pegawai dan orang lain dalam organisasi untuk menghilangkan aktiva perusahaan tanpa sepengetahuan pihak manajemen.

Menurut Arens, dkk. (2008) fraud (kecurangan) yang terjadi dalam organisasi biasanya disebabkan oleh lemahnya kontrol yang dilakukan oleh pihak manajemen, disamping itu fraud juga disebabkan oleh tiga komponen yang biasanya disebut dengan fraud triangle yaitu: insentif/tekanan, kesempatan dan sikap.

Setiap tindakan fraud juga didasari atau dipicu oleh sebuah kondisi dan perilaku penyebab terjadinya. Kondisi inilah yang memunculkan sebuah teori yang banyak digunakan oleh penyidik di Kepolisian yang menyatakan bahwa kriminal (C) sama dengan Niat (N) dan Kesempatan (K). Karena itu, menurut Karyono (2013) teori ini lebih dikenal dengan teori $\mathrm{C}=\mathrm{N}+\mathrm{K}$ yang berarti bahwa fraud sering terjadi bukan saja didasari oleh niat tetapi munculnya fraud disebabkan karena adanya niat dan kesempatan.

Uraian di atas menunjukan bahwa individu baik dilevel top, lini, dan staf yang memiliki wewenang terhadap berbagai sumberdaya berberpotensi berniat dan/atau memiliki kesempatan untuk melakukan penyelewengan atau pemalsuan laporan keuangan. Hasil penelitian yang dilakukan oleh Ernst \& Young dikutip oleh Fitrawansyah (2014) menjelaskan bahwa lima belas persen CCFO, dalam skala global bersedia "mengeluarkan dana" untuk memenangkan kompetisi bisnis atau melanggengkan hegemoni bisnisnya. Kecurangan seperti ini biasanya dilakukan oleh 
manajemen level atas, namun demikian trik atau kecurangan juga dapat dilakukan oleh manajemen level bawah dengan cara melakukan penyuapan kepada agen penjualan untuk memperoleh order, menyuap pemeriksa oknum pajak supaya proses audit dimudahkan serta markup dalam pengadaan barang dan jasa.

Dari sudut pandang auditor, fraud dapat secara luas diklasifikasikan sebagai langkah yang sengaja dilakukan oleh satu atau lebih individu untuk menipu atau menyesatkan dengan tujuannya adalah menggelapkan aset bisnis sehingga mendistorsi kinerja keuangan atau memperoleh keuntungan yang tidak adil. Karena itu fraud perlu untuk diketahui lebih dini penyebabnya. Artinya kecurangan yang terjadi didalam suatu organisasi perlu diidentifikasi secara komprehensif penyebabnya sehingga dapat diminimalisir peluang terjadinya kecurangan yang kronis. Karena itu, menurut Tuanakotta (2013) pencegahan fraud dapat dilakukan dengan mengaktifkan pengendalian internal. Ini berarti, pengendalian internal dapat menjadi penghalang atau mengurangi orang-orang dalam melakukan kecurangan yang dapat merugikan banyak orang termasuk organisasi.

Menurut Pope dikutip oleh Kayo (2013), pencegahan fraud dalam hal pengadaan barang publik, antara lain: pertama, memperkuat kerangka hukum. Alat yang paling ampuh adalah menyingkapkannya kepada publik. Media dapat memainkan peran penting untuk menciptakan kesadaran publik mengenai masalah ini dan untuk membangun dukungan bagi langkah-langkah yang perlu diambil. Jika masyarakat diberi informasi rinci mengenai keburukan dan pelanggaran hukum dalam keterlibatan orang melakukan korupsi, berapa suap yang diterima, berapa kerugian yang timbul dan jika masyarakat terus mendapat informasi seperti ini secara teratur, sulit dibayangkan masyarakat tidak akan menuntut diadakan pembaruan. Kedua, prosedur transparan. Selain dari kerangka hukum, pertahanan berikutnya melawan fraud adalah prosedur dan praktik yang terbuka dan transparan untuk melaksanakan proses pengadaan barang itu sendiri. Belum ada orang yang menemukan cara yang lebih baik untuk melawan fraud dalam pengadaan barang daripada prosedur seleksi pemasok atau kontraktor berdasarkan persaingan yang sehat. Apakah sebuah prosedur rumit atau sederhana tergantung pada nilai dan spesifikasi barang yang akan dibeli, tetapi unsur-unsurnya sama bagi semua prosedur: a) menguraikan dengan jelas dan tanpa memihak apa yang akan dibeli; b) mengumumkan kesempatan untuk menawarkan barang; c) menyusun kriteria untuk mengambil keputusan pada waktu seleksi; d) menerima penawaran dari pemasok yang bertanggung jawab; e) membandingkan penawaran dan menentukan penawaran yang terbaik, menurut peraturan yang telah ditetapkan lebih dahulu bagi seleksi; dan f) memberikan kontrak pada penawar yang menang seleksi tanpa mengharuskannya menurunkan harga atau mengadakan perubahan lainnya pada penawarannya yang menang itu. Ketiga, membuka dokumen tender. Satu kunci untuk mewujudkan transparansi dan sikap tidak memihak adalah pembeli membuka dokumen tender pada waktu dan di tempat yang telah ditetapkan, di hadapan semua pengikut tender atau wakil-wakil mereka yang ingin hadir. Praktik membuka dokumen tender di depan umum, sehingga setiap orang dapat melihat siapa yang mengajukan penawaran dan dengan harga berapa, dapat mengurangi risiko bahwa tender yang bersifat rahasia itu dibocorkan kepada peserta lain, diabaikan, diubah atau dimanipulasi. Keempat, evaluasi penawaran. Evaluasi penawaran adalah langkah yang paling sulit dalam proses pengadaan barang untuk dilaksanakan secara benar dan adil. Bersamaan dengan itu langkah ini adalah salah satu langkah yang paling mudah dimanipulasi jika ada pejabat yang ingin mengarahkan keputusan pemenang pada pemasok tertentu. Para penilai dapat menolak penawaran-penawaran yang tidak diinginkan dengan alasan tertentu. Setelah penawaran diperiksa, jika tidak ada yang menghalangi, para penilai mungkin menetapkan syaratsyarat yang sama sekali baru yang harus diperhitungkan ketika memilih pemenang atau kriteria evaluasi mungkin dibuat demikian 
subjektif tanpa ukuran-ukuran objektif sehingga penilaian dapat menelurkan hasil yang diinginkan para penilai. Kelima, melimpahkan wewenang. Prinsip peninjauan ulang dan audit independen sudah diterima luas sebagai cara untuk menyingkapkan kesalahan atau manipulasi dan memperbaikinya. Prinsip ini menduduki tempat yang penting dalam bidang pengadaan barang publik.

\section{PENGEMBANGAN HIPOTESIS}

\section{Pengendalian Internal terhadap Pencegahan Fraud}

Sunyoto (2014) menyatakan bahwa pengendalian internal merupakan sebuah prosedur yang dirancang untuk memberikan kepastian yang layak bagi manajemen, bahwa perusahaan telah mencapai tujuan dan sasarannya. Ada tiga tujuan umum yang ingin dicapai oleh organisasi dalam menerapkan pengendalian internal yakni keinginan untuk menerapkan keandalan pelaporan keuangan, efesiensi dan efektivitas operasi serta ketaatan pada hukum dan peraturan.

Keandalan pelaporan keuangan, efisiensi dan efektivitas operasi serta ketaatan pada hukum dan peraturan bisa dicapai oleh organisasi manakalah manajemen mampu menerapkan prosedur pengendalian internal yang baik sehingga mampu mencegah terjadinya kecurangan yang berdampak pada ketidakandalan laporan keuangan, efisiensi dan efektivitas operasai dan ketaatan pada hukum dan peraturan. Fraud dapat dicegah melalui pengendalian internal sebagaimana menurut Tuanakotta (2013), dan COSO (1994) bahwa pencegahan fraud dapat dilakukan dengan mengaktifkan pengendalian internal.

Penelitian yang dilakukan oleh Khanna (2009) pada industri perbankan di india menemukan bahwa sistem pengendalian yang kuat dan praktek tenaga kerja yang baik dapat mencegah terjadinya kecurangan. Penelitian ini menejelaskan bahwa kurangnya pelatihan dan banyaknya beban yang dihadapi oleh pegawai serta persaingan dan tingkat kepatuhan yang rendah menjadi alasan utama terjadinya kecurangan. Selain itu, hasil yang sama juga ditunjukkan dalam penelitian yang dilakukan oleh Coram, et al. (2006), bahwa audit internal memberikan nilai tambah melalui peningkatan kontrol dan pemantauan lingkungan dalam organisasi untuk mendeteksi fraud. Hasil penelitian Arfah (2011) menemukan bahwa terdapat pengaruh positif pada penerapan lingkungan pengendalian, penilaian resiko, kegiatan pengendalian, informasi dan komunikasi serta pemantauan baik secara parsial maupun simultan terhadap pencegahan fraud pengadaan barang.

Mendukung temuan di atas, hasil penelitian Shanmugam, et al. (2012) menemukan bahwa pengendalian internal dan langkah-langkah pencegahan fraud akan berdampak pada peningkatan kinerja peruahaan. Sejalan dengan temuan ini, Josiah, Samson, \& Elizabetth (2012) menjelaskan bahwa kecurangan yang terjadi selama ini dalam organisasi merupakan cerminan dari manajemen yang buruk, auditor internal yang terbatas, lemahnya sistem pengendalian internal, serta korupsi. Untuk itu, Omar dan Bakar (2012) menjelaskan dalam penelitian mereka bahwa efektivitas pencegahan kecurangan sangat ditentukan oleh pemeriksaan yang dilakukan oleh intern control serta peran auditor external dalam melaksanakan mekanisme pencegahan kecurangan dalam organisasi. Ini berarti organisasi sektor publik perlu secara konsisten dan kontinyu mengevaluasi laporan keuangan, dan selalu taat pada hukum dan peraturan perundang-undangan yang berlaku, karena hal ini dapat mencegahnya terjadi praktek kecurangan pengadaan barang. Selain itu, pimpinan harus mau mengkomunikasikan berbagai dampak negatif dan positif tentang praktek/perilaku kecurangan kepada seluruh karyawan.

Berdasarkan uraian di atas dirumuskan hipotesis penelitian sebagai berikut:

$\mathrm{H}_{1}$ : Pengendalian internal berpengaruh positif terhadap pencegahan fraud.

\section{Pengendalian Iternal Terhadap Good Corporate Governance}

BPKP mendefiniskan good corporate governance (GCG) merupakan sistem pengendalian dan pengaturan perusahaan yang dapat dilihat 
dari mekanisme hubungan antara berbagai pihak yang mengurus perusahaan (hard definition), maupun ditinjau dari "nilai-nilai" yang terkandung dari mekanisme pengelolaan itu sendiri (soft definition).

Hasil penelitian yang dilakukan oleh Sari (2012) menemukan bahwa pengendalian internal berpengaruh terhadap penerapan good corporate governance, semakin baik pengendalian internal di lingkungan pemerintah maka akan menaikkan transparansi dan akuntabilitas dalam pengelolaan keuangan daerah. Dalam Peraturan Pemerintah No. 8 Tahun 2006 menjelaskan bahwa salah satu tujuan yang ingin dicapai dengan penerapan sistem pengendalian internal adalah untuk memberikan keyakinan yang memadai terkait keandalan penyajian laporan keuangan pemerintah. Sistem pengendalian intern tersebut harus memuat prosedur rekonsiliasi antara data transaksi keuangan yang diakuntansikan oleh Pengguna Anggaran/Kuasa Pengguna Anggaran dengan data transaksi keuangan yang diakuntansikan oleh Bendahara Umum Negara/Daerah.

Hasil penelitian Gusnardi (2011), dan Suyono dan Hariyanto (2012) juga menemukan bahwa pengendalian internal berpengaruh terhadap good corporate governance. Dalam penelitian ini juga ditemukan bahwa pengendalian internal dapat memberikan jaminan dalam keandalan pelaporan keuangan, efisien dan operasi yang efektif, dan sesuai dengan aturan dan peraturan. Oleh karena itu, jika pengendalian internal dalam organisasi berjalan dengan baik, praktek good corporate governance (GCG) yang baik dan benar dapat secara otomatis ditingkatkan.

Hasil yang sama diperlihatkan dalam penelitian yang dilakukan oleh Pratolo (2007) bahwa pengendalian internal dan audit manajemen berpengaruh terhadap prinsipprinsip good coorporate governance.

Berdasarkan uraian di atas dirumuskan hipotesis penelitian sebagai berikut:

$\mathrm{H}_{2}$ : Pengendalian internal berpengaruh positif terhadap good corporate governance.

\section{Good Corporate Governance Terhadap Pencegahan Fraud}

Good corporate governance digunakan dalam rangka mencegah potensi fraud yang terjadi pada perusahaan maupun organisasi sektor publik. Secara prinsip GCG adalah bentuk kode etik dan prinsip-prinsip lain yang digunakan untuk mencegah organisasi dari kejahatan yang bertentangan dengan hukum.

Hasil penelitian yang dilakukan oleh Gusnardi (2011) terhadap 13 BUMN di Indonesia menemukan bahwa pengendalian internal dan pelaksanaan tata kelola perusahaan dapat mencegah terjadinya fraud dalam perusahaan. Artinya bahwa pencegahan fraud dapat dilakukan oleh organisasi manakalah tata kelola perusahan diterapkan dalam organisasi. Hasil penelitian Glover, et al. dikutip oleh Kusmayadi (2012) juga mememukan bahwa penerapan good corporate governance mampu mendeteksi fraud.

Mendukung berbagai temuan di atas, hasil penelitian Zeyn (2012) menjelaskan bahwa penerapan good coporate governance akan meningkatkan transparansi dan akuntabilitas dalam pengelolaan keuangan daerah. Adanya transpransi dan akuntabilitas dalam pengelolaan keuangan akan memperkecil potensi terjadinya kecurangan. Sementara itu, Akintoye, et al. (2011) menjelaskan temuan penelitiannya bahwa penerapan good corporate governance akan meningkatan fungsi pengendalian sehingga dapat mendeteksi ganguan atau hambatan dalam mencapai tujuan yang telah ditetapkan.

Chapple, Forguson dan Kang (2009); dan Agarwal dan Medury (2011) dalam penelitiannya juga menemukan bahwa tata kelola perusahaan yang baik akan mengurangi resiko penyalagunaan aset atau pencegahan fraud. Dalam penelitian Agarwal \& Medury juga menjelaskan bahwa untuk mencegah terjadinya fraud melalui good corpaorate governance, maka perusahaan memerlukan atau menyiapkan auditor yang independen dan profesional. Untuk itu, organisasi sektor publik diharuskan secara konsisten untuk mengimplementasikan prinsip-prinsip Good Corporate Governance (GCG) agar dapat 
mendorong kinerja berbagai sumber daya secara efisien, menghasikan nilai ekonomi jangka panjang yang berkesinambungan bagi para pemegang saham maupun masyarakat sekitar secara keseluruhan.

Berdasarkan uraian di atas dirumuskan hipotesis penelitian sebagai berikut:

$\mathrm{H}_{3}$ : Good corporate governance berpengaruh positif terhadap pencegahan kecurangan (fraud).

\section{METODE PENELITIAN}

Pada bagian ini akan diuraikan mengenai populasi dan sampel, data dan sumber data, pengukuran variabel dan metode analisis.

\section{Populasi dan Sampel}

Penelitian ini dilakukan pada Aparatur Pemerintah pada SKPD Kabupaten/Kota Propinsi Maluku Utara. Populasi dalam penelitian ini adalah Aparatur Pemerintah pada SKPD Kabupaten/Kota di Propinsi Maluku Utara, dan sampel penelitiannya adalah aparatur pemerintah daerah disetiap SKPD Provinsi Maluku Utara yang bertanggungjawab terhadap perencanaan penyusunan anggaran, monitoring dan evaluasi program dan kegiatan. Sebagaimana diketahui bahwa jumlah SKPD di lingkungan Pemprov Maluku Utara adalah sebanyak 134 SKPD. Karena itu, pertimbangan waktu dan biaya penelitian, maka perlu dilakukan penarikan sampel unit populasi (SKPD) dengan menggunakan rumus Slovin dikutip oleh Riduwan (2008) yaitu: $n=N /\left(N \cdot d^{\wedge} 2+1\right), \quad$ sehingga $\quad n=$ $\frac{134}{134 .(0,0)^{2}+1} \frac{134}{1.8576}=72$. Dengan demkian, maka jumlah sampel adalah sebanyak 72 SKPD yang tersebar diseluruh Kabupaten/Kota Pemerintah Provinsi Maluku Utara.

Karena tidak semua Aparatur Negara (PNS) terlibat dalam perencanaan penyusunan anggaran, monitoring dan evaluasi program dan kegiatan pengadaan barang dan jasa, maka metode penarikan sampel yang digunakan adalah purposive non random sampling yaitu: pengambilan sampel secara sengaja sesuai dengan persyaratan sampel yang diperlukan. Dengan demikian, ukuran sampel dalam penelitian ini dapat dilihat pada tabel 1 , dimana jumlah sampel adalah sebanyak 144 orang.

\section{Data dan Sumber Data}

Data dikumpulkan dalam penelitian ini adalah data primer dengan menggunakan kuesioner kepada responden. Sumber data merupakan pendapat dan persepsi dari setiap personil (aparatur) dalam instansi pemerintahan yang bertanggung jawab dalam perencanaan penyusunan anggaran, monitoring dan evaluasi program dan kegiatan.

Tabel 1: Ukuran Sampel

\begin{tabular}{|c|c|c|c|}
\hline No & Pemda Provinsi Maluku Tara & Populasi PNS $(\mathrm{N}) *$ & Sampel PNS (n)** \\
\hline & Malut & 41 & 16 \\
\hline 2. & Kota Ternate & 30 & 18 \\
\hline 3. & Kota Tidore & 24 & 12 \\
\hline 4. & Halteng & 17 & 12 \\
\hline 5. & Halbar & 19 & 12 \\
\hline & Halsel & 21 & 16 \\
\hline & Halut & 29 & 16 \\
\hline & Haltim & 25 & 14 \\
\hline & Kepulauan Sula & 22 & 14 \\
\hline & Morotai & 19 & 14 \\
\hline \multicolumn{2}{|c|}{ Jumlah } & 247 & 144 \\
\hline \multicolumn{4}{|c|}{$\begin{array}{l}\text { Keterangan: } \\
* \text { Jumlah PNS secara keseluruhan masing-masing SKPD Provinsi, dan Kabupaten/Kota } \\
\text { ** Jumlah PNS yang terlibat perencanaan penyusunan anggaran, monitoring dan evaluasi program } \\
\text { dan kegiatan }\end{array}$} \\
\hline
\end{tabular}




\section{Pengukuran Variabel}

Pengendalian Internal $\left(\mathrm{X}_{1}\right)$, variabel ini di ukur dengan instumen pertanyaan yang di dikembangkan dari Arens, dkk. (2008) yang terdiri dari lima indikator lingkungan pengendalian, penilaian resiko, sistem informasi, kegiatan pengendalian dan pemantauan.

Good Corporate Governance $\left(\mathrm{X}_{2}\right)$ variabel diukur dengan menggunakan instrumen yang dikembangkan dari BPKP (2003) yang terdiri dari lima indikator yaitu: 1) transparansi (transparency); 2) partisipasi (participation); 3) akuntabilitas (accountability); 4) kemandirian (independency); dan 5) pertanggungjawaban (responsibility)

Pencegahan Kecurangan (Y) variabel ini di ukur dengan menggunakan instrumen yang digunakan untuk mengukur pencegahan kecurangan terdiri dari tiga indikator yang digunakan oleh Arens, dkk. (2008) yaitu: insentif/tekanan, kesempatan dan sikap.

\section{Metode Analisis Data}

Penelitian ini adalah deskriptif dan verifikatif yang dilaksanakan melalui pengumpulan data primer di lapangan. Karen itu, metodenya adalah metode explanatory survey method dengan mengambil sampel dari suatu populasi dan menggunakan kuesioner sebagai alat pengumpulan data yang utama. Untuk menguji pengaruh antara variabel eksogen dan endogen, maka alat uji yang digunakan
Structural Equation Modeling (SEM) dengan menggunakan program LISREL 8.80.

Berdasarkan pada paradigma penelitian yang diuraikan dalam kajian teori dan prinsip dasar model persamaan struktural, maka pengaruh langsung antara variabel eksogen dan variabel endogen dapat digambarkan dalam bentuk diagram jalur full model (hybrid model) seperti tampak pada gambar 1.

Hair, et al. (2009) menyatakan bahwa didalam SEM akan dilakukan uji kecocokan untuk memeriksa tingkat kecocokan antara data dengan model, validitas dan reliabilitas model pengukuran, dan siginifikansi koefisienkoefisien model struktural. Lebih lanjut dijelaskan bahwa evaluasi terhadap tingkat kecocokan data dengan model dilakukan dengan melalui beberapa tahapan, yaitu: 1) Kecocokan keseluruhan model (overal model fit) yaitu tahap pertama dari uji kecocokan ini ditujukan untuk mengevaluasi secara umum derajat kecocokan (Goodness of Fit Index) dengan kriteria: $P$-value $\geq 0,05=$ model fit, RMSEA $\leq 0,08=$ model fit, dan GFI, AGFI,CFI, NFI dan NNFI $\geq 0,09=$ model fit; dan 2) Analisis Kecocokan Model Pengukuran yaitu evaluasi atau analisis model pengukuran melalui dua tahapan: a) Indikator dikatakan valid jika memiliki bobot faktor lebih besar dari 0,40, dan jika nilai $\mathrm{t}$ factor loading lebih besar dari nilai kritis $(\geq 1,96)$, dan standardized factor loadings $\geq 0,50$, dan b) reliabilitas yang baik jika nilai construct reliability $(\mathrm{CR}) \geq 0,70$, dan nilai variance extarcted $(\mathrm{VE}) \geq 0,50$.

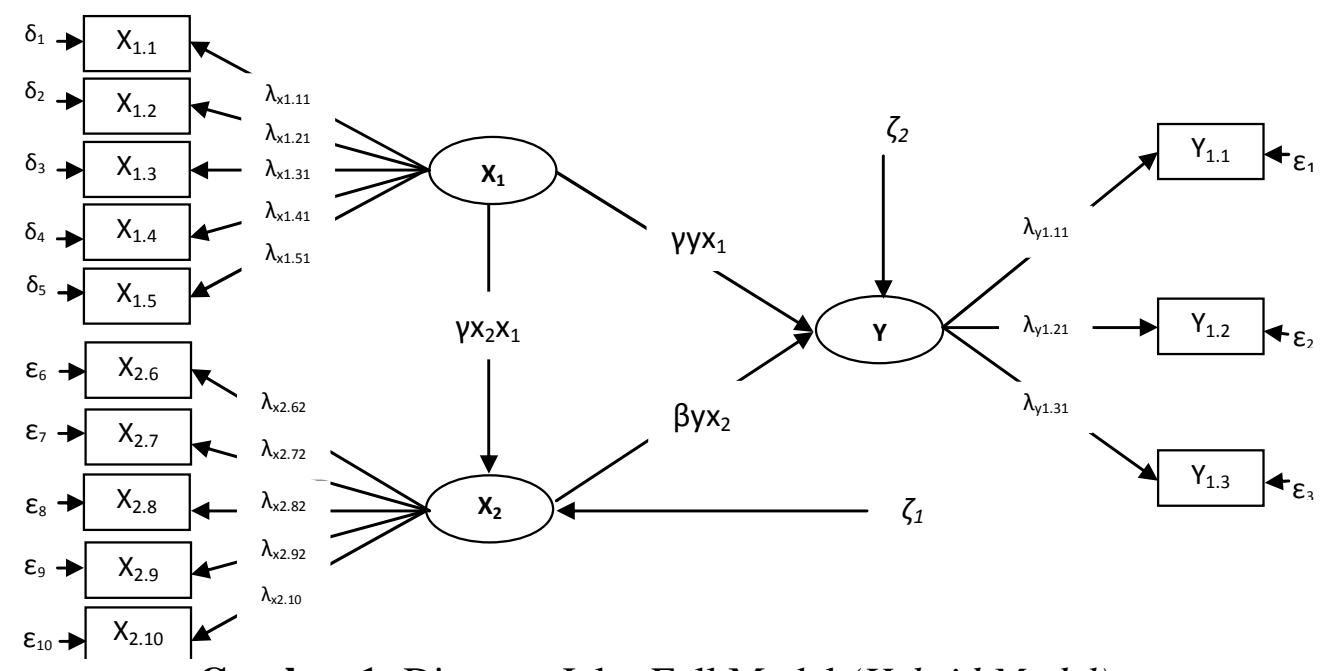

Gambar 1: Diagram Jalur Full Model (Hybrid Model) 
HASIL DAN PEMBAHASAN

\section{Pengujian Normalitas Data (Test of Normality)}

Pada bagian ini dilakukan uji normalitas data (tes of normality) untuk menentukan estimasi apakah yang digunakan dalam pengujian model persamaan struktural dengan LISREL. Hasil uji normalitas secara keseluruhan (multivariate) dapat dilihat pada tabel 2.

Berdasarkan tabel 2 di bawah diperoleh nilai chi-square sebesar 90,097 dengan $p$-value sebesar 0,000 pada skewness and kurtosis yang berrarti bahwa data variabel manifes tidak berdistribusi normal multivariat. Karena itu, menurut Raykov \& Marcoulides (2006) jika distribusi variabel observasi tidak normal dalam suatu penelitian, maka menggunakan metode Satorra-Bentler Robust Maximum Likelihood pada estimasi parameter. Metode estimasi ini pada program lisrel 8.80 digunakan dengan memasukan asymtotic covariance matrix, sehingga model akan diestimasi dalam keadaan data yang tidak normal.

\section{Kecocokan Keseluruhan Model}

Berdasar pengujian SEM dengan LISREL hasil uji kecocokoan keseluruhan model (goodness of fit) dalam structural equation modelling
(SEM) dapat dilihat pada tabel 3. Berdasarkan pada tabel 3, menunjukkan kecocokan model secara keseluruhan (overall) menggunakan uji Satora-Bentler Scaled Probabilitas Chi-square $(X)^{2}$ diperoleh nilai sebesar 66,828 dengan $p$ value $=0,175>0,05$. Berdasarkan hasil uji $\chi^{2}$ maka data empiris edintik dengan teori/model. Pengujian selanjutnya adalah $\mathrm{RMSEA}=0,034$ $<0,08$ yang berarti good fit. Sedangkan hasil uji $\mathrm{GFI}=0,921<0,90$, yang berarti bahwa model memiliki kecocokan yang baik (good fit). Selanjutnya, nilai $\mathrm{CFI}=0,994, \mathrm{NFI}=0,960$, $\mathrm{NNFI}=0,992$, IFI=0,94, dan RFI=0,946 lebih besar dari 0,90 yang berarti bahwa model memiliki kecocokan yang baik (good fit). Selain itu hasil ECVI memiliki nilai yang lebih kecil dari $3(\mathrm{ECVI}=1,751<5)$ yang berarti bahwa, model juga memiliki kecocokan yang baik.

\section{Analisis Kecocokan Model Pengukuran}

Analisis model pengukuran (confirmatory factor analysis-CFA) digunakan untuk menguji validitas dan reliabilitas masingmasing indikator yang membentuk variabel laten. Berdasarkan metode estimasi SatorraBentler robust maximum likelihood diperoleh Hasil uji CFA dapat lihat pada tabel 4.

Tabel 2: Uji Normalitas Data Multivariate

\begin{tabular}{llllllll}
\hline Skewness & & & & Kurtosis & \multicolumn{2}{c}{ Skewness and Kurtosis } \\
\hline Value & Z-Score & P-Value & Value & Z-Score & P-Value & Chi-Square & P-Value \\
\hline 61.446 & 8.314 & 0.000 & 459.141 & 4.580 & 0.000 & 90.097 & 0.000 \\
\hline
\end{tabular}

Tabel 3: Hasil Uji kecocokan Model

\begin{tabular}{ccccc}
\hline No. & Indeks & Hasil & $\begin{array}{c}\text { Nilai yang } \\
\text { Direkomendasikan }\end{array}$ & Kesimpulan \\
\hline 1 & S-BSProbabilitas Chi-square $(X)^{2}$ & 0,175 & $>0,05$ & Goodfit \\
2 & RMSEA & 0,034 & $\leq 0,08$ & Goodfit \\
3 & GFI & 0,921 & $>0,90$ & Good fit \\
4 & CFI, NFI, NNFI, IFI, RFI & $0,994,0,960,0,992,0,994,0,946$ & $>0,90$ & Goodfit \\
5 & ECVI & 0,945 & $<3$ & Goodfit \\
\hline
\end{tabular}

Tabel 4: Hasil Uji Confirmatory Factor Analysis (CFA)

\begin{tabular}{|c|c|c|c|c|c|}
\hline Indikator & Std. Loading & $\begin{array}{l}\text { Error Variance } \\
\text { Berturut-turut }\end{array}$ & $\mathrm{t}$-value $\left(\mathrm{t}_{\mathrm{h}}\right)$ & $\mathrm{CR}$ & VE \\
\hline $\begin{array}{l}\mathrm{X}_{1.1}, \mathrm{X}_{1.2}, \mathrm{X}_{1.3} \\
\mathrm{X}_{1.4}, \mathrm{X}_{1.5}\end{array}$ & $\begin{array}{c}1,00 \cdot 0,86 \cdot 0,70 . \\
0,41.0,58\end{array}$ & $\begin{array}{c}0,00,0,26,0,51 \\
0,83,0,66\end{array}$ & $\begin{array}{c}10,45.7,36.9,25 . \\
4,53.7,11\end{array}$ & 0,848 & 0,547 \\
\hline $\begin{array}{l}\mathrm{X}_{2.6}, \mathrm{X}_{2.7}, \mathrm{X}_{2.8} \\
\mathrm{X}_{2.9}, \mathrm{X}_{2.10}\end{array}$ & $\begin{array}{c}0,92 \cdot 0,74 \cdot 0,82 . \\
0,80 \cdot 0,70\end{array}$ & $\begin{array}{c}0,14.0,46 \cdot 0,33 . \\
0,64 \cdot 0,52\end{array}$ & $\begin{array}{c}7,69.9,41.9,00 \\
8,90.11,18\end{array}$ & 0,883 & 0,605 \\
\hline $\mathrm{Y}_{1.1}, \mathrm{Y}_{1.2}, \mathrm{Y}_{1.3}$ & $0,72.0,68.0,75$ & $0,48 \cdot 0,53 \cdot 0,44$ & $5,90.6,90.7,24$ & 0,761 & 0,516 \\
\hline
\end{tabular}


Berdasarkan Tabel 4 di atas menunjukkan bahwa: 1) lima (5) variabel manifes $X_{1}$ memiliki loading factors standardized solution masing sebesar $\mathrm{X}_{1.1}=1,00, \mathrm{X}_{1.2}=0,86$, $\mathrm{X}_{1.3}=0,70, \quad \mathrm{X}_{1.4}=0,41$, dan $\mathrm{X}_{1.5}=0,58$ lebih besar dari 0,40 , sedangkan $\mathrm{t}_{\mathrm{h}}$ masing-masing sebesar $X_{1.1}=10,450, X_{1.2}=7,360, X_{1.3}=9.250$, $\mathrm{X}_{1.4}=4,530$, dan $\mathrm{X}_{1.5}=7,110$ lebih besar dari $\mathrm{t}_{\text {tabel }}=1,96$ yang berarti bahwa secara keseluruhan indikator tersebut memiliki tingkat validitas yang baik dalam membentuk/mengukur variabel laten (pengendalian internal). Sementara itu, nilai reliabilitas konstruk $(\mathrm{CR})$ pengendalian internal sebesar 0,848 lebih besar dari 0,70 (CR>0,70) dan nilai average variance extracted (VE) sebesar 0,547 lebih besar dari 0,50 (VE>0,50), menunjukan bahwa indikator tersebut memiliki reliabilitas yang baik atau konsisten dalam mengukur variabel laten pengendalian internal; 2) lima (5) variabel manifes $X_{2}$ memiliki loading factors standardized solution masing sebesar $\mathrm{X}_{2.6}=0,920$, $\mathrm{X}_{2.7}=0,740, \quad \mathrm{X}_{2.8}=0,820, \quad \mathrm{X}_{2.9}=0,800, \quad$ dan $\mathrm{X}_{2.10}=0,700$ lebih besar dari 0,40 , sedangkan

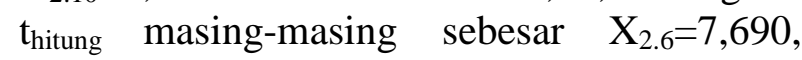
$\mathrm{X}_{2.7}=9,410, \quad \mathrm{X}_{2.8}=9,000, \quad \mathrm{X}_{2.9}=8,900, \quad$ dan $\mathrm{X}_{2.10}=11,180$ lebih besar dari $\mathrm{t}_{\text {tabel }}=1,96$ yang berarti bahwa secara keseluruhan indikator tersebut memiliki tingkat validitas yang baik. Selanjutnya adalah nilai reliabilitas konstruk (CR) good corporate governance sebesar 0,883 lebih besar dari 0,70 (CR>0,70) dan nilai average variance extracted (VE) sebesar 0,605 lebih besar dari 0,50 (VE>0,50), menunjukan bahwa indikator tersebut memiliki reliabilitas yang baik; dan 3) variabel manifes Y memiliki loading factors standardized solution masing sebesar $\mathrm{Y}_{1.1}=0,720, \mathrm{Y}_{1.2}=0,680$ dan $\mathrm{Y}_{1.3}=0,750$ lebih besar dari 0,40 , sedangkan $t_{\text {hitung masing- }}$ masing sebesar $Y_{1}=5,900, \quad Y_{2}=6,900$, dan $\mathrm{Y}_{3}=7,240$ lebih besar dari $\mathrm{t}_{\text {tabel }}=1,96$ yang berarti bahwa secara keseluruhan indikator tersebut memiliki tingkat validitas yang baik. Sebagaimana halnya $\mathrm{X}_{1}$ dan $\mathrm{X}_{2}$, indikator $\mathrm{Y}$ juga memiliki reliabilitas yang baik, karena $\mathrm{CR}=0,761>0,70$, dan $\mathrm{VE}=0,516>0,50$.

\section{Analisis Keocokan Model Struktural}

Berdasarkan hasil olah LISREL 8.80 persamaan sub struktur pertama adalah $\mathrm{X}_{2}=$ $0.548 * \mathrm{X} 1$, Errorvar. $=0.700, \mathrm{R}^{2}=0.300$, sedangkan sub struktur kedua adalah $\mathrm{Y}=$ $0.298 * \mathrm{X} 2+0.424 * \mathrm{X} 1$, Errorvar. $=0.593, \mathrm{R}^{2}=$ 0.407. Berdasarkan pada model sub struktur pertama, menunjukan bahwa besarnya pengaruh langsung pengendalian internal terhadap good corporate governance sebesar 0,548, sedangkan secara simultan adalah sebesar $30,00 \%$, dan sisanya sebesar $70,00 \%$ merupakan pengaruh faktor-faktor lain yang tidak dijelaskan dalam penelitian ini. Sedangkan pada model sub struktur kedua menunjukan pengaruh pengendalian internal dan good corporate governance terhadap pencegahan kecurangan (fraud) secara berturut-turut adalah 0,298 dan 0,424 , sedangkan secara simultan adalah sebesar $40,70 \%$, dan sisanya sebesar $59,30 \%$ merupakan pengaruh faktor-faktor lain yang tidak dijelaskan dalam penelitian ini. Variabel good corporate governance memiliki pengaruh langsung yang lebih besar dari pengendalian internal.

Secara keseluruhan Secara keseluruhan (hybrid model) diagram jalur standardized solution dapat dilihat pada gambar 2 . Berdasarkan pada gambar 2, dapat dijelaskan pengaruh tidak langsung (indirrect effects) $\mathrm{X}_{1}$ terhadap $\mathrm{Y}$ melalui (dimediasi) $\mathrm{X}_{2}$ adalah sebesar $0,55 \times 0,30=0,16$, dan total pengaruh (total effects) adalah sebesar $0,16+0,42=$ 0,58 . Ini berarti bahwa pengaruh pengendalian internal dan good corporate governance bersama-sama mempengaruhi pencegahan fraud lebih besar dari pengaruh secara individu.

\section{Pengujian Hipotesis}

Setelah dilakukan uji kecocokan keseluruhan model, uji model pengukuran (validitas dan reliabilitas) dan uji persamaan struktural, maka selanjutnya akan dilakukan uji hipotesis. Berdasarkan perhitungan koefisien jalur dengan menggunakan Program LISREL 8.80, hasil pengujian masing variabel eksogen dan endogen dapat dilihat pada tabel 5. 


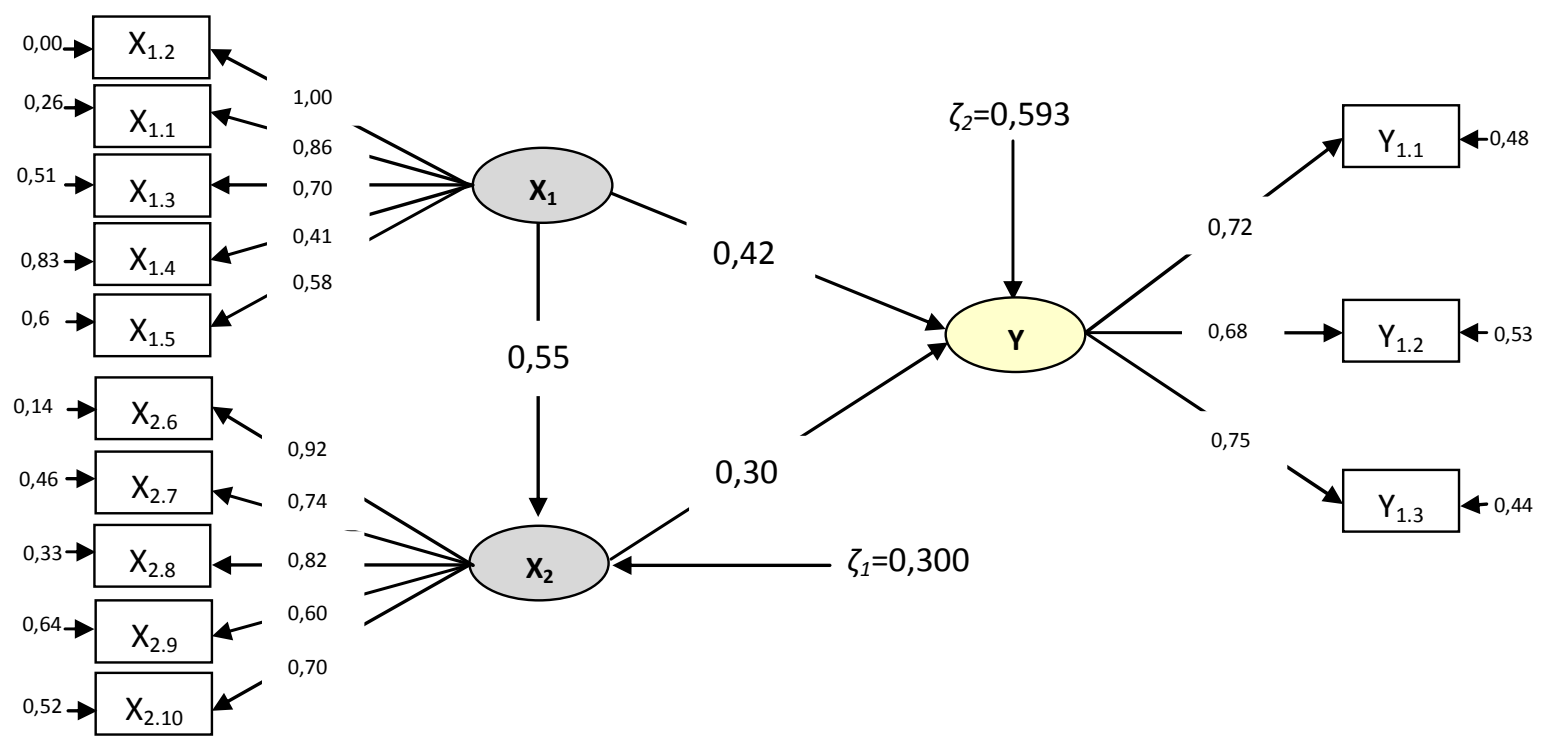

Gambar 2: Hybrid Model Diagram Jalur Standardized Solution

Tabel 5: Rangkuman Hasil Pengujian Pengaruh Langsung Positif Variabel Eksogen dan Endogen

\begin{tabular}{cccccc}
\hline Sampel & Koefisien Jalur & Nilai Koefisien & $\mathrm{t}_{\text {hitung }}$ & $\mathrm{t}_{\text {tabel }(\alpha=0,05)}$ & Kesimpulan \\
\hline 144 & $\gamma \mathrm{yx}_{1}$ & 0,42 & 2,78 & 1,96 & Signifikan \\
144 & $\gamma \mathrm{x}_{2} \mathrm{x}_{1}$ & 0,55 & 4,07 & 1,96 & Signifikan \\
144 & $\gamma \mathrm{yx}_{2}$ & 0,30 & 2,00 & 1,96 & Signifikan \\
\hline
\end{tabular}

Berdasarkan hasil pengujian pada tabel 5 di atas menunjukan koefisien jalur pengaruh positif pengendalian internal terhadap pencegahan kecurangan (fraud) $\left(\gamma \mathrm{yx}_{1}\right)=0,42$ yang memiliki nilai $t_{\text {hitung }}=2,78$ lebih besar dari nilai $t_{\text {tabel }(\alpha=0,05)}=1,96$ yang berarti bahwa $\mathrm{H}_{\mathrm{o}}$ ditolak dan terdapat pengaruh langsung positif pengendalian internal terhadap pencegahan kecurangan (fraud) di Pemerintah Daerah Provinsi Maluku Utara. Secara langsung pengendalian internal memberikan pengaruh sebesar $(0,42)^{2} \times 100 \%=17,64 \%$ terhadap pencegahan fraud. Hasil ini secara teoretik dapat dijelaskan bahwa pengendalian internal diterapkan dalam organisasi guna memberikan kepastian terhadap pencapaian tujuan organisasi. Mayangsari dan Wandanarum (2013) menjelaskan bahwa pengendalian internal adalah penggunaan semua sumberdaya perusahaan untuk meningkatkan, mengarahkan, mengendaliakan dan mengawasi berbagai aktivitas dengan tujuan untuk memastikan bahwa tujuan perusahaan tercapai. Untuk itu, demi tercapainya tujuan perusahaan tersebut, maka prosedur dan kebijakan harus dilakukan oleh perusahaan dengan cara setiap aktivitas yang dilakukan dalam perusahaan harus melalui sebuah sistem yang didesain untuk dapat mengarahkan, dan mengendalikan dan mengawasi rangkaian aktivitas sehingga tujuan perusahaan dapat dicapai secara efisien dan efektif.

Selain hal di atas, hasil penelitian ini konsisten dengan hasil penelitian terdahulu yang dilakukan oleh Josiah, et al. (2012); dan Khanna (2009) menemukan bahwa pengendalian internal yang efektif mampu mencegah terjadinya kecurangan yang dilakukan baik oleh pihak manajemen maupun karyawan. Mendukung temuan ini, Shahbuddin, et al. (2011) dalam hasil penelitiannya menggambarkan bahwa pengendalian internal merupakan sarana bagi organisasi untuk memantau dan mengarahkan sumberdaya organisasi yang dimilikinya, serta memainkan peran penting dalam melakukan pencegahan kecurangan atas sumberdaya yang dimilikinya baik secara fisik maupun non fisik. 
Koefisien jalur pengaruh positif pengendalian internal terhadap good corporate governance $\left(\gamma_{2} \mathrm{x}_{1}\right)=0,55$ yang memiliki nilai $\mathrm{t}_{\text {hitung }}=3,427$ lebih besar dari nilai $\mathrm{t}_{\text {tabel }(\alpha=0,05)}$ = 1,96 yang berarti bahwa $\mathrm{H}_{\mathrm{o}}$ ditolak dan terdapat pengaruh langsung positif pengendalian internal terhadap good corporate governance di Pemerintah Daerah Provinsi Maluku Utara. Secara langsung pengendalian internal memberikan pengaruh sebesar $(0,55)^{2}$ $\times 100 \%=30,25 \%$ terhadap good corporate governance. Hasil ini konsisten dengan konsep BPKP R.I (2003) yang menjelaskan bahwa good corporate governance merupakan sistem pengendalian dan pengaturan perusahaan yang dapat dilihat dari mekanisme hubungan antara berbagai pihak yang mengurus perusahaan (hard definition), maupun ditinjau dari nilai-nilai yang terkandung dari mekanisme pengelolaan itu sendiri (soft definition).

Penelitian ini juga konsisten dengan hasil penelitian terdahulu yang dilakukan oleh Sari (2012); Suyono dan Hariyanto (2012); Gusnardi (2011); dan Pratolo (2007) yang menjelaskan bahwa pengendalian internal yang efektif akan berdampak pada tata kelola perusahaan yang baik, dan dalam perspektif organisasi sektor publik pengendalian internal yang baik akan akan menaikkan transparansi dan akuntabilitas dalam pengelolaan keuangan daerah sehingga akan berhubungan positif terhadap pencapaian Good Corporate Governance.

Koefisien jalur pengaruh postif good corporate governance terhadap pencegahan fraud $\left(\gamma \mathrm{yx}_{2}\right)=0,30$ yang memiliki nilai $\mathrm{t}_{\text {hitung }}=$ 2,00 lebih besar dari nilai $t_{\text {tabel }}(\alpha=0,05)=1,96$ yang berarti bahwa $\mathrm{H}_{\mathrm{o}}$ ditolak dan terdapat pengaruh langsung positif good corporate governance terhadap pencegahan fraud di Pemerintah Daerah Provinsi Maluku Utara. Secara langsung pengendalian internal memberikan pengaruh sebesar $(0,30)^{2} \times 100 \%$ $=9,00 \%$ terhadap pencegahan fraud. Hasil ini konsisten dengan penelitian yang dilakukan oleh Gusnardi (2011) menemukan bahwa pengendalian internal dan pelaksanaan tata kelola perusahaan dapat mencegah terjadinya kecurangan dalam perusahaan. Chapple, et al. (2009); dan Agarwal dan Medury (2011) dalam penelitiannya juga menemukan bahwa tata kelola perusahaan yang baik akan mengurangi resiko penyalagunaan aset atau pencegahan fraud. Ini berarti pelaksanaan tata kelola perusahaan mampu mencegah terjadinya kecurangan, karena secara prinsip tata kelola perusahaan selalu berkaitan dengan sifat keterbukaan, tidak diskriminatif, tanggung jawab yang jelas dan ada kontrol dari masyarakat.

\section{SIMPULAN}

Berdasarkan pengujian hipotesis menghasilkan temuan sebagai berikut: 1) Pengendalian internal berpengaruh positif terhadap Good Corporate Governance. Hal ini menunjukan bahwa tata kelola Pemerintahan yang baik dilakukan dengan menetapkan sistem pengendalian internal dalam setiap aktivitas organisasi dan dapat berjalan dengan efektif jika struktur pengendalian internal dirancang untuk diterapkan secara baik dalam lingkungan organisasi, 2) Good Corporate Governance berpengaruh positif terhadap pencegahan fraud. Hal ini menunjukan bahwa pencegahan fraud dapat dilakukan dengan mengeleminsasi faktor-faktor pendorong terjadinya kecurangan dengan menerapkan prinsip prinsip good corporate governance yaitu transparansi, akuntabilitas, kewajaran, integritas dan partisipasi, dan 3) Pengendalian internal berpengaruh positif terhadap pencegahan fraud. Hal ini menunjukan pencegahan fraud dilakukan melalui pengendalian internal dengan cara mengurangi tekanan, kesempatan dan perbaikan moral individu pada setiap level dalam organisasi. Oleh karena itu maka: (1) Untuk meningkatkan tata kelola atau good corporate governance dilingkungan organisasi sektor publik dengan melakukan restrukturisasi politik birokrasi dan korporasi, karena faktor inilah yang menjadi awal terjadinya korupsi dan malpraktek yang terjadi di lingkungan Pemerintah Daerah Provinsi Maluku Utara. Untuk itu pemberantasan praktek-praktek fraud selain dengan menata sumberdaya yang dimilikinya juga harus memiliki sistem 
pengendalian internal secara komprehensip agar dapat mencegah terjadinya fraud dan pimpinan harus menetapkan prioritas, mengkoordinasikan strategi dan mengkomunikasikannya ke seluruh manajemen dan staf. (2) Untuk penelitian berikutnya disarankan untuk menggunakan variabel lain seperti asymetri informasi, external auditor dan kompensasi.

Skain itu, kaitannya dengan Good Corporate Governance, Pemerintah Daerah Provinsi Maluku Utara dapat meningkatkannya melalui evaluasi faktor Pengendalian internal yaitu lingkungan pengendalian, penilaian resiko, sistem informasi, kegiatan pengendalian dan pemantauan; dan terkait dengan pencegahan fraud, Pemerintah Daerah selain pengendalian internal dievaluasi, perlu juga mengevaluasi faktor good corporate governance yaitu terkait dengan transparansi, partisipasi, akuntabilitas, kemandirian, dan pertanggungjawaban. Hal ini perlu dilakukan, karena secara emprik terbukti memiliki kemampuan untuk mencegah terjadinya fraud.

\section{DAFTAR PUSTAKA}

Agarwal, G. K., dan Y. Medury. 2011. Good governance a tool to prevent corporate fraud. International Journal of Commerce, Bussines and Management 2 (6): 318-327.

Akintoye, I. R., R. O. Akingunola, dan J. E. Oseni. 2011. In efective corporate governance: Challenger of internal audit function. Internationa Journal of Research in Comerce \& Management 2 (3): 16-22.

Albrecht, W. S., C. C. Albrecht, C. O Albrecht, dan M. Zimbelman. 2009. Financial fraud: How and why. European Business Forum (Quated in the Time of London) 27.

Arens, A.A., R.J. Elder, dan M. S. Beasley. 2008. Auditing dan jasa assurance pendekatan Tterintegrasi. Jilid I Edisi Keduabelas, Jakarta: Erlangga.

Arfah, A. E. 2011. Pengaruh penerapan pengendalian internal terhadap pen- cegahan fraud pengadaan barang dan implikasinya pada kinerja keuangan (Studi pada Rumah Sakit Pemerintah dan Swasta di Kota Bandung). Jurnal Investasi 7 (2): 137-153.

Asian Development Bank. 1999. Corporate governance and finance in East Asia. A. Study of Indonesia, Republic of Korea, Malaysia, Philippines, and Thailand. Editted By: Ma Virginita Capulong, David Edwards, David Webb, and Juzhong Zhuang, Vol. 1 and Vol. 2.

Association of Cerified Fraud Examiners (ACFA). 2012. Report to nations on occouptional fraud and abuse.

BPKP R.I 2003. Tim Corporate Governance BPKP Modul 1 Good corporate governance: Dasar-dasar corporate governance. Jakarta.

Chapple, L., C. Forguson, dan D. Kang. 2009. Corporate governance and misappropriation. JFAI 1 (2): 1-26.

Coram, A. P., A. C. Ferguson, dan B. R Moroney. 2006. The value of internal audit in fraud detection. Diakses dari www.google.com pada 10 Maret 2013.

COSO. 1994. Internal control intergrated framework. New York: AIGPA' $s$ Publication Devision.

Fitrawansyah. 2014. Fraud \& auditing. Jakarta: Mitra Wacana Media.

Gusnardi. 2011. Pengaruh peran komite audit, pengendalian internal, audit internal dan pelaksanaan tata kelola perusahaan terhadap pencegahan kecurangan. Jurnal Ekuitas 15 (1): 130-146.

Hair, Jr. J. F., W. C. Black, B. J Babin, dan R. E. Anderson. 2009. Multivariate data analysis (sixth edition). New Jersey: Pearson Prentice Hall Education International.

Ikatan Akuntan Indonesia (IAI). 2001. Standar akuntansi akuntan publik. SA Seksi 319, Pertimbangan Atas Pengen- 
dalian Intern dalam Audit Laporan Keuangan.

Josiah, M., A. A Samson, dan O. A. Elizabetth. 2012. Evaluation of roles of auditors in fraud detection and investigation in Nigerian Industries. American Journal of Social and Management Sciences 3 (2): 21561540.

Karyono. 2013. Forensic fraud. Yogyakarta: Andi.

Kayo, S. A. 2013. Penggunaan dan kompetensi auditor dalam pemberatasan tindak pidana korupsi. Jakarta: Graha Ilmu.

Khanna, A. 2009. A Study to investigate the reason for bank frauds and the implementation of preventive security controls in Indian banking industri. Int Journal of Bussines Science and Applied Management 4 (3): 1-21.

Komite Nasional Kebijakan Governance (KNKG). 2006. Pedoman umum good corporate governance di Indonesia. Jakarta: Komite Nasional Kebijakan Governance (KNKG).

Kusmayadi, D. 2012. Determinasi audit internal dalam mewujudkan good corporate governance serta implikasinya terhadap kinerja bank. Jurnal Keuangan dan Perbankan 16 (1): 147156.

Laporan Hasil Pemeriksaan BPK Semester I Tahun 2013. Diakses dari www.google.com pada 10 Maret 2013.

Liu, J., dan B. Lin. 2012. Government auditing and corruption control: Evidence from Chinas's Provincial panel data. China Journal of Accounting Research 5 (1): 163-186.

Mardiasmo 2000. Akuntansi sektor publik. Jogjakarta: Andi.

Mayangsari dan Wandanarum 2013. Auditing pendekatan sektor publik dan privat. Jakarta: Media Bangsa.
Omar, N., dan A. M. K Bakar. 2012. Fraud prevention mechanisms of government linked companies: An assesment of existence and effectiviness. Journal of Modern Accounting and Auditing 8 (1): 15-30.

Peraturan Pemerintah No. 8 Tahun 2006. Tentang pedoman pelaksanaan pengadaan barang/jasa pemerintah.

Pratolo, S. 2007. Good corporate governance dan kinerja BUMN di Indonesia: Aspek audit manajemen dan pengendalian intern sebagai variabel oksegen serta tinjauannya pada jenis perusahaan. Seminar Nasional Akuntansi IX Makassar.

Raykov, T., dan G. A. Marcoulides. 2006. A first course in structural equation modeling, Second Edition. Mahwa New Jeresy London: Lawrence Erlbaum Associates, Inc.

Riduwan. dan A. K. Engkos. 2008. Cara menggunakan dan memaknai analisis jalur path analysis. Cetakan kedua, Bandung: Alfabeta.

Sari, D. 2012. Pengaruh pengendalian internal terhadap transparansi laporan keuangan Pemerintah Daerah. Pre ceding Seminar Nasional Akuntansi dan Bisnis: 718-727.

Shahbuddin, A. M., A. Alam, dan M. M. Azad. 2011. Internal control in management information system. International Journal of Computer Informations System 2 (6): 68-78.

Shanmugam, K. J., A. Ali, dan C. H. M. Haat. 2012. An explanatory study of internal control and fraud prevention measures in SMEs. International Journal of Bussines Research and Management 3 (2): 90-99.

Siaran Pers BPK RI. 2013. Diakses dari www.bpk.co.id. pada 28 Februari 2013. 
Sukrisno, A. 2012. Auditing petunjuk praktis pemeriksaan akuntan oleh Akuntan Publik (Jilid I Edisi Keempat), Jakarta: Salemba Empat.

Sunyoto, D. 2014. Auditing pemeriksaan akuntansi. Yogyakarta: CAPS (Center of Academic Publishing Service).

Suyono, E., dan E. Hariyanto. 2012. Relationship between internal control, internal audit, and organizational commitment with good governance: Indonesian case. Journal China -USA Bussines Review 11 (9): 1237-1245.

Tuanakotta. T. 2013. Audit berbasis ISA (International Standards on Auditing). Jakarta: Salemba Empat.

Tunggal, A. W. 2011. Teori dan kasus kecurangan akuntansi keuangan. Jakarta: HARVINDO.

Tunji, T. S. 2013. Efective internal control system as antidote for distress in banking industry in Nigeria. Jorunal of Economic and International Business Research (JEIBR) 1 (5): 106-121.
Undang-Undang Nomor 1 Tahun 2004, Tentang perbendaharaan negara.

Undang-Undang Nomor 15 Tahun 2004, Tentang pemeriksaan dan pengelolaan keuangan negara.

Undang-Undang Nomor 17 Tahun 2003, Tentang keuangan negara.

United Nation Development Program (UNDP). 1997. Governance for sustainable human development. Diakses dari http://www.pogar.org//publication/oth er/undp/governance/undppolicy. pada 15 April 2013.

Wells, J. T. 2007. Corporate fraud handbook: Prevention and detection (second edition), John Wiley and Sons Inc.

Zeyn, E. 2011. Pengaruh good governance dan standar akuntansi Pemerintahan terhadap akuntabilitas keuangan dan komitmen organisasi sebagai pemoderasi. Jurnal Review Akuntansi dan Keuangan 1 (1): 21-37. 